\title{
Oral Mucocele-A Mini Review
}

\section{Prasanna Kumar Rao ${ }^{1 *}$, Shishir Ram Shetty ${ }^{2}$, Laxmikanth Chatra ${ }^{1}$ and Prashanth Shenai}

${ }^{1}$ Department of Oral Medicine and Radiology, Yenepoya Dental College, Yenepoya University, Deralakatte, Nithyanandanagar Post, Mangalore, Karnataka, India ${ }^{2}$ Department of Oral Medicine and Radiology, AB Shetty Memorial Institute of Dental Science, Nitte University, Deralakatte, Nithyanandanagar Post, Mangalore, Karnataka, India

\begin{abstract}
Mucoceles are the common salivary gland disorder which can be present in the oral cavity, appendix, gall bladder paranasal sinuses or lacrimal sac. Common location for these lesions in the oral cavity is lower lip however, it also presents on other locations like tongue, buccal mucosa, soft palate, retromolar pad and lower labial mucosa. Trauma and lip biting habits are the main cause for these types of lesions. These are painless lesions which can be diagnosed clinically.
\end{abstract}

Keywords: Mucoceles; Lower lip; Laser ablation; Retention cyst

\section{Introduction}

Mucocele is defined as mucous filled cavities that can appear in the oral cavity, appendix, gall bladder, paranasal sinuses or lacrimal sac $[1,2]$. The term mucocele is derived from a Latin word, mucus and coele means cavity [3]. Mucocele is seventeenth most common salivary gland lesions seen in the oral cavity [4]. This is the result of accumulation of mucous due to the alteration in the minor salivary gland which causes limited swelling [5].

\section{Types}

Clinically there are two types, extravasation and retention type (Figure 1). Extravasation type is due to the leaking of fluid from the broken salivary gland ducts and acini into the surrounding soft tissues. This type of mucocele is seen in minor salivary glands. Retention type is due to the blockage of salivary gland duct and this type is commonly seen in major salivary gland ducts [6]. Clinically there is no difference between extravasation and retention type of mucoceles. When this mucocele is located in floor of the mouth it appears as the underbelly of a frog, so it is called as ranula [1].

These lesions are devoid of epithelial lining and are also termed as:

- Superficial mucocele

- Classical mucocele

Superficial mucoceles are located under the mucous membrane and classical mucoceles are seen in the upper submucosa [1,7].

\section{Etiopathogenesis}

There are mainly two important etiological factors which are highlighted [8]. They are,

- Trauma

- Obstruction of salivary gland duct

Mainly physical trauma can cause spillage of salivary secretion

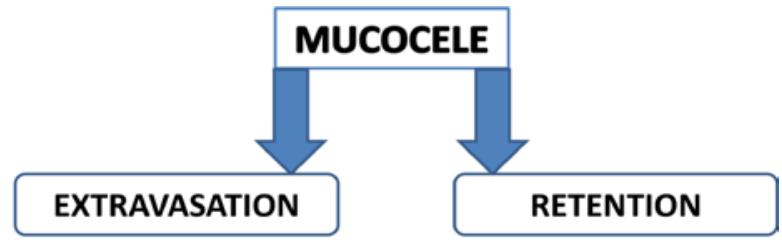

Figure 1: Types of Mucocele. into surrounding submucosal tissue. Later inflammation may become obvious due to stagnated mucous [6]. Habit of lip biting and tongue thrusting are also one of the aggravating factors [9].

The extravasation type will undergo three evolutionary phases [10].

In first phase, there will be spillage of mucous from salivary duct in to the surrounding tissue in which some leucocytes and histiocytes are seen. In second phase, granulomas will appear due to the presence of histiocytes, macrophages and giant multinucleated cells associated with a foreign body reaction. This second phase is called as resorption phase. Later in third phase, there will be a formation of pseudocapsule without epithelium around the mucosa due to connective cells.

The retention type of mucocele is commonly seen in major salivary glands. It is due to the dilation of duct due to block caused by a sialolith or dense mucosa [10]. It depends upon the obstruction of salivary flow from secretory apparatus of the gland [11].

\section{Clinical Characteristics}

Mucocele is the common salivary gland disorder and it is second most common benign soft tissue tumor in the oral cavity [12]. They are characterized by accumulation of mucoid material with rounded, well circumscribed transparent, bluish colored lesion of variable size. It is a soft and fluctuant asymptomatic swelling with rapid onset which frequently resolves spontaneously $[13,14]$. Common in the lower lip but may occur in other locations also [15]. The bluish discolouration is mainly due to the vascular congestion and cyanosis of the tissue above and the fluid accumulation below. It also depends on the size of the lesion and proximity to the surface and upper tissue elasticity $[1,16]$.

Sizes may vary from few millimeters to centimeters and occurs single in number, rarely bilateral $[11,17]$. They are usually doom shaped swellings with intact epithelium over it. Sometimes superficial

*Corresponding author: Dr. Prasanna Kumar Rao J, Associate Professor Department of Oral Medicine and Radiology, Yenepoya Dental College, Yenepoya University, Nithyananda Nagar Post, Deralakatte, Mangalore, 575018, Karnataka, India, Tel: +919900151108; E-mail: drjpkrao@gmail.com

Received October 17, 2012; Accepted November 23, 2012; Published November 25, 2012

Citation: Prasanna Kumar Rao, Shishir Ram S, Laxmikanth C, Prashanth S (2013) Oral Mucocele-A Mini Review. Dentistry 3: 153. doi:10.4172/2161-1122.1000153

Copyright: @ 2013 Bortoluzzi MC, et al. This is an open-access article distributed under the terms of the Creative Commons Attribution License, which permits unrestricted use, distribution, and reproduction in any medium, provided the original author and source are credited. 
mucocele with single or multiple blisters are seen on the soft palate, retromolar pad, posterior buccal mucosa and lower labial mucosa, which rupture spontaneously and become ulcerated mucosal surface which heals within few days [9]. It is seen equally in males and females more in first, second and third decade of life [7].

The differential diagnosis which can be considered are BlandinNuhn and mucocele, benign or malignant salivary gland neoplasms, Oral Hemangioma, Oral Lymphangioma, Venousvarix or venous lake, Lipoma, Soft irritation fibroma, Orally lymphoepithelial cyst, Gingival cyst in adults, Soft tissue abscess, and Cysticercosis. Superficial mucoceles may be confused with Cicatricial pemphigoid, Bullous lichen planus and Minor aphthous ulcers [9].

\section{Diagnosis}

The appearance of mucocele is pathognomonic, and so the data about the lesion location, history of trauma, rapid appearance, variations in size, bluish color and the consistency $[16,18,19]$. Usually this lesion is soft and of elastic consistency, which is depends on tissue present over the lesion [16]. History and clinical finding will lead to the diagnosis of superficial mucocele. Fine needle aspiration demonstrates the mucus retention, histiocytes and inflammatory cells [20]. In retention type mucoceles cystic cavity with well defined epithelial wall, covered with cuboidal cells are present. This type shows less inflammatory reaction [19]. The extravasation type was pseudocyst without epithelial wall and shows inflammatory cells and granulation tissues [19]. Chemical analysis shows high amylase and protein content. Radiographs are the contributing factors in cases of ranulas. Localization of these lesions is done by Computed Tomography and Magnetic Resonance Imaging [9].

\section{Treatment}

Conventional surgical removal is a most common method used to treat this lesion. Other treatment options include $\mathrm{CO}_{2}$ laser ablation, cryosurgery, intralesional corticosteroid injection, micro marsupialization, marsupialization and electrocautery [21-23,3]. Some studies suggested the initial use of cryosurgical approach or intralesional corticosteroid injection, but cases of relapses in these techniques is more [23]. Both extravasation and retention type of mucoceles clinically appears same so that the treatment option for both the types are same. Small sized mucoceles are removed with marginal glandular tissues and in case of large lesions marsupialization will helps to avoid vital structure damage and decrease the risk of damaging the labial branch of mental nerve [23]. Lacrimal catheters are used to dilate the duct to remove the obstruction of retention type mucoceles $[1,9]$. While removing the mucocele surgically, remove the surrounding glandular acini, removing the lesion down to the muscle layer, and avoiding the adjacent gland and duct damage while placing the suture. This will reduce the chances of recurrence $[1,23]$. If the fibrous wall of the mucocele is thick then the removed tissue must be sent for histopathological examination to rule out any salivary gland neoplasms [9]. The micro marsupialization was considered as ideal treatment in case of pediatric patient because this technique was simple, rapid and prognosis is good. The advantage in $\mathrm{CO}_{2}$ laser is that it minimizes the relapses and complications and allows rapid, simple mucocele ablation. It is also indicated for the patients who cannot tolerate long procedures [23].

\section{Conclusion}

Mucocele is the most common benign self-limiting condition. It is commonly seen in young males. Trauma was the most common cause and majority of these lesions are seen in the lower lips. Majority of the cases can be diagnosed clinically however sometimes biopsy is required to rule out any other types of neoplasms. Different types of treatment options are available but the $\mathrm{CO}_{2}$ laser treatment shows more benefits with less relapses. As mucocele is painless, dentists are the one who notice these types of lesions and diagnose.

\section{References}

1. Baurmash HD (2003) Mucoceles and ranulas. J Oral Maxillofac Surg 61: 369 378.

2. Ozturk K, Yaman H, Arbag H, Koroglu D, Toy H (2005) Submandibular gland mucocele: report of two cases. Oral Surg Oral Med Oral Pathol Oral Radio Endod 100: 732-735

3. Yagüe-García J, España-Tost AJ, Berini-Aytés L, Gay-Escoda C (2009) Treatment of oral mucocele-scalpel versus C02 laser. Med Oral Patol Oral Cir Bucal 14: e469-e474

4. Flaitz CM, Hicks JM (2012) Mucocele and ranula. eMedicine.

5. Bagán Sebastián JV, Silvestre Donat FJ, Peñarrocha Diago M, Milián Masane MA (1990) Clinico-pathological study of oral mucoceles. Av Odontoestomatol 6: 389-391, 394-395.

6. Boneu-Bonet F, Vidal-Homs E, Maizcurrana-Tornil A, González-Lagunas J (2005) Submaxillary gland mucocele: presentation of a case. Med Oral Patol Oral Cir Bucal 10: 180-184.

\section{Selim MA, Shea CR, Mucous cyst. eMedicine.}

8. Yamasoba T, Tayama N, Syoji M, Fukuta M (1990) Clinicostatistical study of lower lip mucoceles. Head Neck 12: 316-320.

9. Gupta B, Anegundi R, SudhaP, Gupta M (2007) Mucocele: Two Case Reports $\mathrm{J}$ Oral Health Comm Dent 1: 56-58.

10. Ata-Ali J, Carrillo C, Bonet C, Balaguer J, Peñarrocha M, et al. (2010) Ora mucocele: review of the literature. J Clin Exp Dent 2: e18-e21.

11. Baurmash $\mathrm{H}$ (2002) The etiology of superficial oral mucoceles. J Oral Maxillofac Surg 60: 237-238.

12. Eveson JW (1988) Superficial mucoceles: pitfall in clinical and microscopic diagnosis. Oral Surg Oral Med Oral Pathol 66: 318-322.

13. Bermejo A, Aguirre JM, López P, Saez MR (1999) Superficial mucocele: report of 4 cases. Oral Surg Oral Med Oral Pathol Oral Radiol Endod 88: 469-472.

14. Seifert G, Miehlke A, Haubrich J, Chilla R (1986) Diseases of the salivary glands. Stuttgart: GeorgThiemeVerlag.

15. Bentley JM, Barankin B, Guenther LC (2003) A review of common pediatric lip lesions: herpes simplex/recurrent herpes labialis, impetigo, mucoceles, and hemangiomas. Clin Pediatr (Phila) 42: 475-482.

16. López-Jornet $P$ (2007) Labial mucocele: a study of eighteen cases. The Internet Journal of Dental Science 3.

17. Andiran N, Sarikayalar F, Unal OF, Baydar DE, Ozaydin E (2001) Mucocele of the anterior lingual salivary glands: from extravasation to an alarming mass with a benign course. Int J Pediatr Otorhinolaryngol 61: 143-147.

18. Guimarães MS, Hebling J, Filho VA, Santos LL, Vita TM, et al. (2006) Extravasation mucocele involving the ventral surface of the tongue (glands of Blandin-Nuhn). Int J Paediatr Dent 16: 435-439.

19. Layfield LJ, Gopez EV (2002) Cystic lesions of the salivary glands: cytologic features in fine-needle aspiration biopsies. Diagn Cytopathol 27: 197-204.

20. López-Jornet $P$, Bermejo-Fenoll A, Point of Care: What is the most appropriate treatment for salivary mucoceles? Which is the best technique for this treatment? J Can Dent Assoc 70: 484-485.

21. Ishida CE, Ramos-e-Silva M (1998) Cryosurgery in oral lesions. Int J Dermato 37: 283-285.

22. Kopp WK, St-Hilaire H (2004) Mucosal preservation in the treatment of mucocele with CO2 laser. J Oral Maxillofac Surg 62: 1559-1561.

23. Huang IY, Chen CM, Kao YH, Worthington P (2007) Treatment of mucocele of the lower lip with carbon dioxide laser. J Oral Maxillofac Surg 65: 855-888. 